\title{
Chocolate, Air Pollution and Children's Neuroprotection: What Cognition Tools should be at Hand to Evaluate Interventions?
}

\author{
Lilian Calderón-Garcidueñas ${ }^{1,2 *}$, Vanessa San Juan Chávez ${ }^{2}$, \\ Nora B. Vacaseydel-Aceves ${ }^{2}$, Raymundo Calderón-Sánchez ${ }^{2}$, Edgar Macías-Escobedo ${ }^{3}$, \\ Carmen Frías ${ }^{4}$, Marcela Giacometto ${ }^{5}$, Luis Velasquez ${ }^{5}$, Renata Félix-Villarreal ${ }^{6}$, \\ Jessie D. Martin ${ }^{7}$, Christopher Draheim ${ }^{7}$ and Randall W. Engle ${ }^{7}$ \\ ${ }^{1}$ Biomedical Sciences, University of Montana, Missoula, MT, USA, ${ }^{2}$ Universidad del Valle de México, Ciudad de México, \\ Mexico, ${ }^{3}$ Psychology, Universidad Autónoma de Coahuila, Saltillo, Mexico, ${ }^{4}$ Universidad Anáhuac, Mérida, Mexico, \\ ${ }^{5}$ Facultad de Medicina, Universidad Andrés Bello, Santiago de Chile, Chile, ${ }^{6}$ Universidad Panamericana, Ciudad de México, \\ Mexico, ${ }^{7}$ School of Psychology, Georgia Institute of Technology, Atlanta, GA, USA
}

OPEN ACCESS

Edited by:

Filippo Caraci,

University of Catania, Italy

Reviewed by:

Fabio Tascedda,

University of Modena, Italy

Rabia Latif,

University of Dammam, Saudi Arabia

*Correspondence:

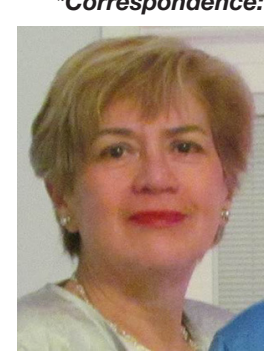

Lilian Calderón-Garcidueñas

$M A, M D, P h D$, is a physician whose

love for exploring disease causes

started in medical school at the

National University of Mexico (UNAM) and took her to pursue her studies in the USA and Canada. She earned an

American Board in Anatomical

Pathology and Neuropathology in

1981 and a PhD in Toxicology at UNC

in 2001. Urban children with high

exposures to PM2.5 and ozone

showing systemic inflammation, immunodysregulation at both systemic

and brain levels, oxidative stress, neuroinflammation, and the hallmarks for Alzheimer and Parkinson's are the

focus of her research.

lilian.calderon-garciduenas @umontana.edu
Millions of children across the world are exposed to multiple sources of indoor and outdoor air pollutants, including high concentrations of fine particulate matter $\left(\mathrm{PM}_{2.5}\right)$ and ozone $\left(\mathrm{O}_{3}\right)$. The established link between exposure to $\mathrm{PM}_{2.5}$, brain structural, volumetric and metabolic changes, severe cognitive deficits (1.5-2 SD from average IQ) in APOE 4 heterozygous females with $>75-<94 \%$ BMl percentiles, and the presence of Alzheimer's disease (AD) hallmarks in urban children and young adults necessitates exploration of ways to protect these individuals from the deleterious neural effects of pollution exposure. Emerging research suggests that cocoa interventions may be a viable option for neuroprotection, with evidence suggesting that early cocoa interventions could limit the risk of cognitive and developmental concerns including: endothelial dysfunction, cerebral hypoperfusion, neuroinflammation, and metabolic detrimental brain effects. Currently, however, it is not clear how early we should implement consumption of cocoa to optimize its neuroprotective effects. Moreover, we have yet to identify suitable instruments for evaluating cognitive responses to these interventions in clinically healthy children, teens, and young adults. An approach to guide the selection of cognitive tools should take into account neuropsychological markers of cognitive declines in patients with Alzheimer's neuropathology, the distinct patterns of memory impairment between early and late onset $A D$, and the key literature associating white matter integrity and poor memory binding performance in cases of asymptomatic familial AD. We highlight potential systemic and neural benefits of cocoa consumption. We also highlight Working Memory Capacity (WMC) and attention control tasks as opened avenues for exploration in the air pollution scenario. Exposures to air pollutants during brain development have serious brain consequences in the short and long term and reliable cognition tools should be at hand to evaluate interventions.

Keywords: air pollution, Alzheimer, children, chocolate, Mexico City, neuroinflammation, neuroprotection, working memory 


\section{BACKGROUND}

Increasing evidence links two key effects of air pollution (oxidative stress and neuroinflammation), to developmental neurotoxicity and neurodegenerative disease, particularly Alzheimer's disease (AD) (Blass and Gibson, 1991; CalderónGarcidueñas et al., 2002, 2008a,b,c, 2012a,b, 2015a,b,c,d,e,f,g; Block and Calderón-Garcidueñas, 2009; Smith et al., 2010; Levesque et al., 2011a,b, 2013; Bolton et al., 2012; Oppenheim et al., 2013; Costa et al., 2014; Jung et al., 2015; Naini and Soussi-Yanicostas, 2015; Yao et al., 2015).

Children are exposed to significant amounts of complex mixtures of air pollutants, and their developing brains are at high risk for deleterious effects (Annavarapu and Kathi, 2016; Forns et al., 2015; Miller et al., 2016; Yorifuji et al., 2016). Sources of air pollutants include common environmental pollutants, molds, and fine particulate matter $\left(\mathrm{PM}_{2.5}\right)$ (Querol et al., 2008; Molina et al., 2010; Múgica et al., 2010; Vega et al., 2010; Lippmann et al., 2013; Amato et al., 2014; Miller et al., 2016). $\mathrm{PM}_{2.5}$ is particularly dangerous for children's health (Bilenko et al., 2015), and factors such as particle size range, geographic location, source category, residency within a city, season, and socioeconomic status, all influence the impact on adverse health effects (Calderón-Garcidueñas and Torres-Jardón, 2012; Hajat et al., 2015). Systemic inflammation and increased concentrations of potent vasoconstrictors (i.e., endothelin-1, ET1) are critical features of children's exposure to the pollution (Calderón-Garcidueñas et al., 2007). Further, this inflammatory response correlates with cumulative exposures to $\mathrm{PM}_{2.5}$ (as well as total outdoor exposure hours), and occurs in conjunction with sustained inflammation of the upper and lower respiratory tracts and endothelial dysfunction (Calderón-Garcidueñas et al., 2003, 2007, 2008b).

Our work has centered specifically on Mexico City children, as they are exposed to a significant amount of pollution daily, including concentrations above the current US standards for ozone, and fine particulate matter $<2.5 \mu \mathrm{m}$ in diameter (Molina et al., 2010). These life-long exposures are very significant in terms of oxidative stress, neurotoxicity, and neurodegeneration (Calderón-Garcidueñas et al., 2008a, 2009, 2012a, 2013a).

A crucial paper focused on the interaction between gender, BMI and APOE 4 makes a key observation: Gender, BMI and APOE influence children's cognitive responses to air pollution and glucose is likely a key player. We have described APOE 4 heterozygous females with $>75-<94 \%$ BMI percentiles have the highest risk of severe cognitive deficits (1.5-2 SD from average IQ). These young females need gender-targeted health programmes to improve their cognitive responses. These are the females at the highest risk for the developing of Alzheimer and thus the need for early multidisciplinary intervention strategies (Calderón-Garcidueñas et al., 2016).

A recent paper by Jung et al. (2015), is highly relevant to the massive exposure of millions of people to high concentrations of air pollutants in megacities: an estimated $211 \%$ higher risk for $\mathrm{AD}$ per increase of $10.91 \mathrm{ppb}$ in $\mathrm{O}_{3}$, and a $138 \%$ risk of increase of $\mathrm{AD}$ per increase of $4.34 \mu \mathrm{g} / \mathrm{m}^{3}$ in $\mathrm{PM}_{2.5}$. The study was done in a cohort of 95,690 individuals' age $\geq 65$, over a 9 year follow-up period. Jung et al.'s findings strongly suggest long-term exposure to $\mathrm{O}_{3}$ and $\mathrm{PM}_{2.5}$ above the current US EPA standards are associated with increasing the risk of $\mathrm{AD}$.

\section{KEY CONCEPT 1 | Air pollutants and Alzheimer's risk}

Long-term exposure to ozone $\left(\mathrm{O}_{3}\right)$ and fine particulate matter $\left(\mathrm{PM}_{2.5}\right)$ above the current US EPA standards is associated with increased risk of AD (Jung et al., 2015).

A key consequence of air pollution exposure is neuroinflammation (Campbell et al., 2009; Levesque et al., 2011a,b, 2013). In urban children, our work has shown a significant frontal lobe imbalance in key genes for inflammation, oxidative stress, innate and adaptive immune responses, cell proliferation, and apoptosis (Calderón-Garcidueñas et al., 2012a). Moreover, otherwise clinically healthy Mexico City children exhibit cognition deficits, brain metabolic, structural and volumetric changes, and the neuropathological and cerebrospinal fluid (CSF) hallmarks of $\mathrm{AD}$ and Parkinson's diseases i.e., tau hyperphosphorylation with pre-tangles, amyloid beta42 (A $\beta 42$ ) plaques, low CSF $\mathrm{A} \beta 42$, and misfolded $\alpha$ synuclein accumulation (Calderón-Garcidueñas et al., 2008a, 2011, 2012a, 2013a, 2015a).

Extensive literature supports human and animal, breakdown of the nasal/olfactory blood-brain-barrier, alveolar-capillary, and intestinal barriers, as well as the brain expression of detrimental genes associated to urban air pollution (Thomson et al., 2007; Gerlofs-Nijland et al., 2010; Villarreal-Calderon et al., 2010; Bolton et al., 2012; Calderón-Garcidueñas et al., 2012a, 2013c, 2015g; Bergin and Witzmann, 2013; Carson et al., 2013; Kish et al., 2013; Ljubimova et al., 2013; Win-Shwe et al., 2014; Rossner et al., 2015; Tsamou et al., 2016). Specifically, inductively coupled plasma mass spectrometry for metal analysis and real time PCR in frontal samples of Mexico City children and young adults showed higher concentrations of metals associated with PM: manganese $(p=0.003)$, nickel and chromium $(p=0.02)$ along with higher frontal COX 2 mRNA $(p=0.008)$ and $\operatorname{IL} 1 \beta(p=0.0002)$ and $\operatorname{COX} 2(p=0.005)$ olfactory bulb indicating neuroinflammation. Olfactory bulb DNA repair genes changes correlated with frontal combustion-related metals, suggesting that PM-metal neurotoxicity plays a key role in brain damage in young urbanites (Calderón-Garcidueñas et al., 2013c). Upregulated gene network clusters involved in inflammation, immunity, differentiation, cell growth, tumorigenesis, and apoptosis, including IL1, NFKB, TNF, IFN, and TLRs are described in frontal samples of MC young urbanites $\mathrm{v}$ clean air controls (Calderón-Garcidueñas et al., 2012a). While a 15-fold frontal down-regulation of the prion-related protein $(\operatorname{PrP}(\mathrm{C}))$ with important roles for neuroprotection, neurodegeneration, and mood disorder states is also seen in highly exposed subjects (Calderón-Garcidueñas et al., 2012a). Upregulation of inflammatory genes is not restricted to supratentorial structures, the dorsal vagal complex (DVC) is also a target (Villarreal-Calderon et al., 2010). Cyclooxygenase-2 (COX-2), interleukin 1 beta (IL-1 $\beta$ ), and CD14 messenger RNA (mRNA) were quantified after 4,8 , and 16 months of exposure 
in mice target brain regions. After 16 months of exposure to the MC atmosphere $\mathrm{v}$ controls, the DVC exhibited significant inflammation in MC mice (COX-2 and IL-1 $\beta P<0.001)$ along with the olfactory bulb upregulation of $\operatorname{CD} 14(P=0.002)$ and significant DVC imbalance in genes for antioxidant defenses, apoptosis, and neurodegeneration. Similar gene cluster changes are seen upon exposure to diesel PM or a combination of PM +ozone (Gerlofs-Nijland et al., 2010; Levesque et al., 2011a,b, 2013; Ljubimova et al., 2013).

Neuroinflammation, cognitive deficits, weight gain, memory function and maternal performance based on the impaired gene expressions in the hippocampus and hypothalamus and placental epigenetic changes with fetal impact are described for specific pollutants such as diesel, as well as a combination of complex mixtures of PM2.5 (Bolton et al., 2012; Win-Shwe et al., 2014; Tsamou et al., 2016).

Of particular concern in environments with high concentrations of ultrafine particulate matter (UFPM, nanosize particles $<100 \mathrm{~nm}$ ), is that UFPM ends up in contact with the vascular endothelium where it can induce damage (Gehr et al., 2011; Sharma and Sharma, 2012; Sharma et al., 2013; Karmakar et al., 2014; Ucciferri et al., 2014). There is robust evidence that nanosize particles can increase endothelial paracellular permeability in vitro, and induce endothelial TJ opening (Sharma et al., 2013; Karmakar et al., 2014; Ucciferri et al., 2014). Exposure to different size particulate matter (including nano size particulate matter), is associated with production and deposit of misfolded protein aggregates (amyloid, alpha synuclein, hyperphosphorilated tau), oxidative stress, cell damage, and death in susceptible neuronal populations (Qin et al., 2007; Hartz et al., 2008; Levesque et al., 2011a,b, 2013; Mushtaq et al., 2015; Parveen et al., 2015; Tian et al., 2015). The frontal white matter is an early and key target of air pollution exposures in young Mexico City residents (Calderón-Garcidueñas et al., 2015f). Major light and electron microscopic findings include: leaking in capillaries and small arterioles, thickening of cerebrovascular basement membranes with small deposits of amyloid, patchy absence of the perivascular glial sheet, enlarged Virchow-Robin spaces and nanosize particles $(20-48 \mathrm{~nm})$ in endothelium, basement membranes, mitochondria, axons and dendrites (Calderón-Garcidueñas et al., 2015f). In canine studies, tight junctions, a key component of the neurovascular unit (NVU) are abnormal in Mexico City vs. rural control dogs $\left(\chi^{2}<0.0001\right)$, and white matter perivascular damage is significantly worse in MC dogs ( $p=0.002$ ) (Calderón-Garcidueñas et al., 2015f). The integrity of the NVU, an interactive network of vascular, glial and neuronal cells is compromised in MC young residents.

\section{KEY CONCEPT 2 | Mexico City children's brains}

Extensive neuroinflammation, breakdown of the neurovascular unit, oxidative stress, and hallmarks of Alzheimer disease pathology are present in the brains of Mexico City children and young adults with chronic yearlong exposures to high levels of $\mathrm{O}_{3}$ and $\mathrm{PM}_{2.5}$.

The issue of early oxidative stress is particularly important in pediatric cohorts, given findings suggesting that "a vicious downward spiral involving the interactions between mitochondrial dysfunction and oxidative stress contributes to the initiation and/or amplification of reactive oxygen species that is critical to the pathogenesis of AD" (Wang X. et al., 2014).

Neuroprotection is critical for pediatric and young adult populations residing in highly polluted environments and given our previous experience using cocoa and dark chocolate to decrease neuroinflammation and improve cognition in young Mexico City residents (Villarreal-Calderon et al., 2010; CalderónGarcidueñas et al., 2013b), we undertook a review of potential systemic and CNS benefits of cocoa consumption. We also explored the use of cognitive assessments, and their ability to identify early, subtle changes in cognitive performance.

\section{NEUROPROTECTION: CHOCOLATE, AN ANCIENT FRIEND AND A NEW PLAYER}

Cocoa health benefits have been appreciated for centuries (Latif, 2013; Sokolov et al., 2013; Grassi et al., 2015a,b). The health benefits of cocoa are numerous and wide ranging. Not the least of which include positive impacts on pathways associated with neurodegeneration (Schini-Kerth, 2014; De la Monte, 2014; Jumar and Schmieder, 2016). Because of the multifaceted nature of $\mathrm{AD}$ pathology, neuroprevention should include targeting multiple potential pathophysiological mechanisms (Dubner et al., 2015). A fundamental issue in using cocoa as a neuroprotector, is to take into account factors that determine absorption, metabolism, and excretion of cocoa flavonols, all of which are key aspects of evaluating potential benefits (Cifuentes-Gómez et al., 2015). Moreover, the presence of flavonols in complex food matrices, including their interactions with other nutrients/non-nutrients, significantly influence their absorption in the intestinal lumen, as well as their transfer across the GI barrier (Cifuentes-Gómez et al., 2015). For example, in pediatric and young adult populations with high exposure to air pollutants, the transfer of flavonols across the GI barrier could be compromised by the extensive tight junction (TJs) damage (Calderón-Garcidueñas et al., 2015g), and the production of TJs autoantibodies (Calderón-Garcidueñas et al., 2015c). Additionally, carbohydrate interactions are critical for the flavonol GI absorption; subsequently, in children, the absorption and metabolism results of the combination of cacao with sugar vs. sucrose, milk (of varying fat content), or lactose intolerance can't be dismissed (Dehkordi et al., 1995; Schramm et al., 2003; Schroeter et al., 2003; Roura et al., 2008; RodriguezMateos et al., 2012; Cifuentes-Gómez et al., 2015).

The issue of brain bioavailability is also important. The passage of the active metabolites through the blood-brain-barrier $(\mathrm{BBB})$, and the detection of certain metabolites in specific brain regions depend on multiple factors. These may include: the type of metabolite (i.e., flavonols, flavonones), lipophilicity of each compound, use of pure compounds, and the integrity of the BBB (Abd El Mohsen et al., 2002; Youdim et al., 2004; Milbury and Kalt, 2010; Faria et al., 2014).

Strategies designed to explain the mechanisms by which brainbioavailable flavonols may beneficially influence cognitive deficits need to be made available (Wang et al., 2010; Wang J. et al., 
2014; Dubner et al., 2015). Several recent papers review the direct, and indirect, mechanisms potentially associated with cocoa's beneficial neural effects (Desideri et al., 2012; Sokolov et al., 2013; Jumar and Schmieder, 2016; Grassi et al., 2015a,b). Overall, evidence suggests that cardiovascular effects are important in neuroprotection, specifically with regard to the impact on endothelial dysfunction (Jumar and Schmieder, 2016). To this end, cocoa flavonols improve vasodilatory capacity in high and low cardiovascular risk subjects (Heiss et al., 2003; Ferri et al., 2015; Jumar and Schmieder, 2016; Sansone et al., 2015). Given the obesity epidemic, and comorbid health problems in Mexico and the USA, cocoa and cocoa flavonoids may positively affect the pathophysiological mechanisms involved in insulin resistance and endothelial dysfunction, with potential benefits in the prevention of cardiometabolic diseases (Grassi et al., $2015 a, b)$. The issue of insulin resistance and diabetes mellitus is important because epidemiological studies support that type 2 diabetes is a major contributor to $\mathrm{AD}$ risk (Cermakova et al., 2015; Ramos-Rodríguez et al., 2015; Sato and Morishita, 2015), and growing evidence supports the key concept that Alzheimer's disease is a metabolic disease, mediated by impairments in brain insulin responsiveness, glucose utilization, and energy metabolism, which ultimately lead to increased oxidative stress, inflammation, and worsening of insulin resistance (De la Monte, 2014).

Thus, lowering blood pressure, inhibiting platelet aggregation, increasing the bioavailability of nitric oxide and reducing inflammatory mediators are critical factors for optimizing cardiovascular health (Ostertag et al., 2010; Ferri et al., 2015; Jumar and Schmieder, 2016; Gormaz et al., 2016) as well as the central nervous system (Fisher et al., 2006; Sorond et al., 2010).

There is a long list of beneficial neural effects of cocoa including: epigenetic mechanisms targeting multiple classes of chromatin writer-reader-eraser proteins related to histone acetylation-methylation and DNA methylation, improvement of memory and learning through enhanced dentate gyrus function, and decreased anxiety with elevated hippocampal monoamine and Brain Derived Neurotrophic Factor (BDNF) levels (Van Praag et al., 2007; Brickman et al., 2014; Stringer et al., 2015; Declerck et al., 2016). However, researchers agree that knowledge of the ultimate action of cocoa flavonols on the human brain remains limited (Sokolov et al., 2013). Moreover, there is a paucity of cocoa flavonols studies on mood, cognitive and cardiovascular health research in young people (Francis et al., 2006; Field et al., 2011; Scholey and Owen, 2013; Massee et al., 2015), and very little research on the effects of cocoa in urban children, a population which could benefit immensely from cocoa interventions (Calderón-Garcidueñas et al., 2013b).

If we are going to use cocoa as a neuroprotectant in otherwise healthy urban children and young adults, more research is needed, including:

1. To define cocoa cognitive effects in the target urban highly exposed population and the clear air counterparts.

2. To define vascular effects, both systemic, and cerebral.

3. To define antidiabetic, antistress, antiobesity, and antiinflammatory effects.
4. To define the health risks from sustained administration of cocoa, including weight gain, alteration of lipid profiles and allergies.

\section{KEY CONCEPT 3 | Cocoa and neuroprotection}

Cocoa's beneficial neural effects include the impact on endothelial function and their positive effects on insulin resistance. There is a knowledge gap in the potential beneficial and detrimental effects of long term administration of cocoa in clinically health young urbanites.

Equally important to the potential for cocoa to serve as a neuroprotector, is the access to a quantifiable measure of its cognitive impact. As such, repeated cognitive testing in teens and young adults is essential.

Of key importance to select the right cognitive tools is the documented evidence that clinically healthy Mexico City children and young adults exhibit the neuropathological and cerebrospinal fluid (CSF) features associated with $\mathrm{AD}$, i.e., tau hyperphosphorylation with pre-tangles, amyloid beta42 (A $\beta 42)$ diffuse plaques, and low CSF A $\beta 42$ (Calderón-Garcidueñas et al., 2008a, 2011, 2012a, 2013a, 2015a). Thus, an approach to guide the selection of cognitive tools should take into account neuropsychological markers of cognitive declines in patients with Alzheimer's neuropathology, the distinct patterns of memory impairment between early and late onset $\mathrm{AD}$, and the key literature associating white matter integrity and poor memory binding performance in cases of asymptomatic familial AD.

\section{NEUROPSYCHOLOGICAL MARKERS OF COGNITIVE DECLINE IN ASYMPTOMATIC FAMILIAL AD, COGNITIVELY HEALTH OLDER ADULTS WITH AD NEUROPATHOLOGY AND PATIENTS WITH EARLY AD}

There is agreement that the pathological hallmarks of Alzheimer disease are present before the onset of symptoms significant to trigger a clinical diagnosis of mild cognitive impairment (MCI) or dementia (Driscoll et al., 2006; Twamley et al., 2006; Grober et al., 2008; Howieson et al., 2008; Price et al., 2009; Riley et al., 2011; Sperling et al., 2011; Beach et al., 2012; Monsell et al., 2014; Hassenstab et al., 2015; Pettigrew et al., 2015). A particularly interesting study from Hassenstab et al. (2015) examined 314 elderly individuals cognitively healthy at study entry. These individuals died within 2 years of their last minimum two visits for neuropsychological performance evaluation and received a diagnosis of low to high $\mathrm{AD}$ neuropathological change. The main cognitive abnormal findings at baseline involved nearly all domains of cognition, with pronounced effects on executive functioning, language and episodic memory. Monsell et al., reported subjects with $\mathrm{AD}$ neuropathological change but without MCI or dementia, having subtle decline in the attention/working memory (WM) domain. Hassenstab et al. (2015) suggested attention/WM might be the earliest subtle neuropsychological domain to be affected in the preclinical phase of $A D$. 
In the work of Chapuis et al. (2016) 76 people with MRI were rated for microangiopathy, hippocampal and parietal atrophy and a gradient of fronto-parietal atrophy. A standardized neuropsychological battery for attention, language, praxis, parietal function, visuoconstructive function, verbal and visual memory, WM, and frontal executive function were used. Working memory (WM) deficits proved to be a reliable battery among the three groups characterized by microangiopathy, hippocampal atrophy and parietal atrophy. It is key to emphasize that microangiopathy indeed is associated with executive disorders and impaired WM (Au et al., 2006; Schmidt et al., 2007; Son et al., 2012), because indeed Mexico City youngsters have significant white matter alterations in the neurovascular unit, with clear evidence of microangiopathy (Calderón-Garcidueñas et al., 2015f).

The white matter integrity as measured by diffusion tensor magnetic resonance imaging is critical to explain poor memory binding performance in symptomatic carriers of the E280A mutation of the PSEN1 gene (Parra et al., 2015).Interestingly, asymptomatic young carriers of the mutation, ages $24-43$ year differed from controls only in the short-term memory binding task. Parra's paper is critical for our review because frontal white matter alterations have an impact on WM (Owen, 2000; Prabhakaran et al., 2000; Sala and Courtney, 2007). Alterations in myelin, oligodendrocytes, axonal degeneration and vascular pathology are key factors to play a role in frontal white matter to account for WM deficits (Englund and Brun, 1990; Sjobeck et al., 2005; Bartzokis et al., 2007). Equally relevant to Mexico City young residents is the knowledge that white matter synaptic disruption precedes both white matter tract anomalies and neurodegeneration (Alix and Domingues, 2011). We fully agree with Parra et al., that "different memory binding functions may be affected by different white matter events."

The issue of impairments of WM and inhibitory control are absolutely critical in the context of air pollution exposures and WM deficits. Eye-tracking tasks deficits are seen in people with early dementia (Crawford et al., 2005, 2013, 2015; Crawford and Highm, 2016). Saccadic eye movements (rapid gaze shifts) are under the control of a network of cortical and subcortical connections involved in WM and inhibitory control (IC) (Crawford and Highm, 2016). The anti-saccade task (AST) is the most common used IC paradigm that includes a central inhibitory component with a high proportion of corrective eye movements following the inhibition failures (Crawford et al., 2013). The corrective eye movements are less frequent in people with AD (Crawford et al., 2013), so it remains to be seen whether highly exposed Mexico City youngsters are impaired on the antisaccade task and if impaired WM can coexist with an intact IC, as suggested by Crawford and Highm (2016).

High levels of eye movement distractibility are seen in the early stages of $\mathrm{AD}$ (Crawford and Highm, 2016), such a deficiency in the ability to inhibit irrelevant information will significantly impact memory. Also relevant, prominent non-memory domains, including executive functions and visuoconstructional abilities are common in early onset $\mathrm{AD}$ (EOAD) (Joubert et al., 2016).
Mexico City children have significantly lower CSF $A \beta_{1-42}$ concentrations vs. their matched clean air controls (CalderónGarcidueñas et al., 2015a). This poses a key question in the open exposed urban population: are the CSF levels of $\mathrm{A} \beta_{1-42}$ relevant for cognition? The information so far is not clear when cognitively normal middle age and older adults are examined. Pettigrew et al. work suggests CSF $A \beta_{1-42}$ is not significantly associated with cognition, while robust associations between biomarkers of amyloid pathology and episodic memory are found (Pike et al., 2007; Villemagne et al., 2011; Hedden et al., 2012; Kantarci et al., 2012; Pettigrew et al., 2015). Interestingly, Pettigrew et al. also reported that APOE4 status was not directly associated with cognitive performance, an association we have reported in our Mexico City highly exposed children' cohorts (Calderón-Garcidueñas et al., 2015b,e).

\section{KEY CONCEPT 4 | Detection of children at high risk}

Our efforts to design a neurocognitive battery for highly exposed Mexico City young residents capable to detecting subtle cognition changes in specific domains, is based on the literature reports focusing in the asymptomatic stages of familiar $A D$ and in the profile of cognitive deficits reported for clinically cognitively intact middle and older adults with $A D$ neuropathology and in patients with early AD.

\section{WORKING MEMORY CAPACITY AND INHIBITORY CONTROL}

It is important that serious thought be given to the measurement of cognition in studying the effects of air pollution. Considerations should include: (1) measures of cognition should be as common across studies as possible, (2) measures should be as domain-general as possible-meaning they should reflect processes and capabilities that are common to many different cognitive tasks, (3) the measures and the constructs they reflect should be moderately well understood in cognitive theory, and (4) they should be relatively easily measured across different environments and in different ages. Working memory and its related constructs meets all these criteria. Working memory capacity (WMC) can be defined as the ability to store or keep active information temporarily for use in ongoing tasks, to update, transform, and modify that information in ongoing processing, and, when necessary to disengage or to inhibit recently activated information (Engle and Kane, 2004). Working memory capacity is highly correlated with fluid intelligence (Gf), the biological and largely inherited aspect of intelligence. One important reason for this correlation seems to be that both types of measures rely on the ability to control ones attention, a capability often referred to as Executive Attention (EA). Extensive work under the rubric of cognitive control (e.g., WMC/Gf/EA) has shown that these capabilities are important to a huge range of educational and real-world cognitive tasks from reading and listening comprehension to complex learning and problem solving (Engle and Kane, 2004; Kane et al., 2004). Thus, the assessment of these constructs can be useful, and even necessary, to be able to make conclusions about the role of 
pollution on cognitive performance of individuals in their own environment.

We have selected key WMC/Gf/EA tasks for exploring highly exposed teens and young adults in Mexico City including.

\section{Complex Spans}

Complex span tasks, the most commonly used measures of WMC have been shown to reflect strong relationships with real-world cognition (Daneman and Carpenter, 1980). We will work with two variations: operation and symmetry span that require test-participants to remember serially-presented items (e.g., letters, words, spatial locations). Each to-be-remembered item is followed by a processing task that has to be completed before the next item is shown and which serves to force attention shifts back and forth between the items to be remembered and the processing task. For the operation span task, a mathematical equation must be solved. For the symmetry span task, a picture must be judged as either symmetrical or non-symmetrical. After several pairs of items and processing tasks have been presented (generally 2-7), test-takers are to reconstruct the list of items in the order in which they were originally presented. Performance on complex span tasks is strongly predictive of a person's attention control abilities (Engle and Kane, 2004; Unsworth et al., 2009; Unsworth and Spillers, 2010; Hutchison, 2011). Key to the quest for subtle cognitive alterations in air pollution, complex span tasks best predict performance on complex cognition tasks (e.g., reading, listening, complex learning, and problem solving) as well as for emotional and behavioral self-control associated with control of inappropriate social behavior (Broadway et al., 2010). Thus, reductions in measures of cognitive control (e.g., WMC/Gf/EA) are associated with a wide range of socially relevant behaviors including, alcohol abuse and violence. Addiction behaviors and violence deserve study because are relevant potential consequences of the effects of pollution on cognitive control.

\section{Attention Control Tasks}

There are two aspects of attention. One way to think about attention is that various events capture our attention. Those events could be externally generated such as a loud sound or internally generated such as the thought of something that happened to you recently. However, the more important aspect of attention for present purposes is how we exert control over our attention and direct it toward a task we are attempting to perform. We can think of that as EA. A good example of this is our tendency to mind wander. It is now clear that people who are measured higher on tasks of cognitive control are much less likely to have their attention captured and to mind wander when performing a task (Kane and McVay, 2012).

There are several reliable and valid tasks of attention control.

\section{One of them is the Antisaccade Task}

In a common version of this task, subjects are faced with a computer screen with a fixation cross in the center of the screen and two boxes 11 degrees of visual angle to each side of the fixation. They are to stare at the fixation cross and at some point one of the boxes will flicker. When they happens they are to immediately shift their attention to the box on the opposite side of the screen where a letter (either O or Q) will be presented for a very short duration $(150 \mathrm{~ms})$ after which it is masked. The subject must identify which letter was presented. The problem is that evolution has prepared all organisms with a brain to have their attention captured by the flickering box because the flicker affords movement in the natural world and things that move can eat you or you can eat them. This tasks requires that individuals resist that natural temptation and force their attention to the opposite side of the screen (Kane et al., 2001). Antisaccade performance is highly associated with WMC and Gf and predicts many different real-world behaviors including self-control.

\section{Flanker Task}

The arrow flanker task based on work by Eriksen and Eriksen (1974) in which subjects are to identify the middle character of a 5 character string. For example, in the string of character $\mathrm{X}$ $\mathrm{X} \rightarrow \mathrm{XX}$, the subject would be required to press a key indicating a right facing as opposed to left facing arrow. In the following string of characters, $\leftarrow \leftarrow \rightarrow \leftarrow \leftarrow$, the response is the same but the subject must resist the strong automatic activation of the response associated with the competing and more numerous arrows pointing left. As in the antisaccade task, performance on this task is strongly predictive of a wide range of cognitive and emotional behaviors (Kane et al., 2004).

\section{General Fluid Intelligence Tasks}

Modern theories of intelligence generally distinguish two types of intelligence: Crystallized intelligence is culturally-derived knowledge such as vocabulary and other things that we have learned from our environment and fluid intelligence, our ability to reason and solve problems which are novel to us. Fluid intelligence is thought to be the biological and genetically derived aspect of intelligence and is the most domain-general. Therefore, it is the aspect of intelligence that is of most interest to our studies of the effects of air pollution. Measures of fluid intelligence, abbreviated as Gf are:

1. Raven's advanced progressive matrices (Raven, 1990). Participants see a $3-3$ matrix in which 8 abstract figures have been placed. Participants chose which of several options belonged in the ninth box. Ten minutes are given to complete 18 problems. The dependent variable is the number of correct responses.

2. Letter sets (Ekstrom et al., 1976). Participants see five sets of four-letter sequences. They need to discover the rule that is common to four of the sets and then indicate which set does not belong. Five minutes are given to complete 30 problems. The dependent variable is the number of correct responses.

3. Number series (Thurstone, 1938). Participants see a series of numbers and select which of several options complete the series. Five minutes are given to complete 15 problems. The dependent variable is the number of correct responses.

All WM tasks have strong, direct, relationships to attention control. It is difficult to maintain to-be-remembered items while alternately performing secondary processing tasks (Shipstead et al., 2014, 2015). Attention control requires engagement in the 
service of organizing the contents of primary memory (Engle, 2002; Kane et al., 2007).

The relationship between attention control, fluid intelligence, and WM capacity is of great relevance to people exposed to environmental air pollution. Any effect that attention control has on novel reasoning is realized through an effect on memory and also fluid intelligence. The issue is then to define in highly exposed individuals the capability for cognitive control as reflected by tasks of WM capacity, fluid intelligence, and EA.

Since the individual's ability to resist attention capture explains a large portion of both WM capacity and its relationship to higher cognitive abilities (Shipstead et al., 2014), the critical point in the results of highly exposed air pollution cohorts vs. clean matched low pollution controls will be to define the interaction of attention control and memory. This in turn, will give us a picture of the impact of environmental factors upon both WM capacity and fluid intelligence in a developing brain. Equally important in terms of the risk of developing Alzheimer, will be the identification of individuals at the highest risk, defined by the lower scores in the tasks measuring WMC and attention control. We already know of the strong relationship between chronic exposure above the standards of ozone and $\mathrm{PM}_{2.5}$ and risk of newly diagnosed Alzheimer disease as clearly shown by Jung et al. (2015).

Since the prevalent consensus is that AD starts decades before clinical diagnosis, and given that these at-risk children and young adults already exhibit WM capacity deficits reflective of well documented systemic and neural pathological changes, the delineation of the relative temporal trajectories of cognitive measures will be key in the evaluation of cocoa administration

\section{REFERENCES}

Abd El Mohsen, M. M., Kuhnle, G., Rechner, A. R., Schroeter, H., Rose, S., Jenner, P., et al. (2002). Uptake and metabolism of epicatechin and its access to the brain after oral ingestion. Free Radic. Biol. Med. 33, 1693-1702. doi: 10.1016/S0891-5849(02)01137-1

Alix, J. J., and Domingues, A. M. (2011). White matter synapses: form, function, and dysfunction. Neurology 76, 397-404. doi: 10.1212/WNL.0b013e3182088273

Amato, F., Rivas, I., Viana, M., Moreno, T., Bouso, L., and Reche, C. (2014). Sources of indoor and outdoor $\mathrm{PM}_{2.5}$ concentrations in primary schools. Sci. Total Environ. 490, 757-765. doi: 10.1016/j.scitotenv.2014.05.051

Annavarapu, R. N., and Kathi, S. (2016). Cognitive disorders in children associated with urban vehicular emissions. Environ. Pollut. 208, 74-78. doi: 10.1016/j. envpol.2015.09.036

Au, R., Massaro, J. M., Wolf, P. A., Young, M. E., Beiser, A., Seshadri, S., et al. (2006). Association of white matter hyperintensity volume with decreased cognitive functioning: the Framingham Heart Study. Arch. Neurol. 63, 246-250. doi: 10.1001/archneur.63.2.246

Bartzokis, G., Lu, P. H., and Mintz, J. (2007). Human brain myelination and amyloid beta deposition in Alzheimer's disease. Alzheimers Dement. 3, 122-125. doi: 10.1016/j.jalz.2007.01.019

Beach, T. G., Monsell, S. E., Phillips, L. E., and Kukull, W. (2012). Accuracy of the clinical diagnosis of Alzheimer disease at National Institute on Aging Alzheimer Disease Centers, 2005-2010. J. Neuropathol. Exp. Neurol. 71, 266-273. doi: 10.1097/NEN.0b013e31824b211b

Bergin, I. L., and Witzmann, F. A. (2013). Nanoparticle toxicity by the gastrointestinal route: evidence and knowledge gaps. Int. J. Biomed. Nanosci. Nanotechnol. 3, 1-44. doi: 10.1504/ijbnn.2013.054515 or any other intervention. The application of the selected tasks, would allow the creation of a framework for the early identification of neurodegeneration biomarkers related to air pollution exposures. Current knowledge should give us the opportunity to intervene in young urban populations, independent of what specific air pollutants are responsible within the complexity of the atmospheric chemistry and the microenvironments of each subject.

As such, an essential goal of future work will be to elucidate the extent of beneficial and potential detrimental effects of chronic cocoa administration to children and young adults and whether it provides real benefits with respect to reducing cognitive impairment.

Exposures to air pollutants during brain development have serious brain consequences in the short and long term and reliable cognition tools should be at hand to identify individuals at their highest risk and to evaluate neuroprotective interventions.

\section{AUTHOR CONTRIBUTIONS}

LC planned and directed the study, wrote the manuscript, edited and formatted the manuscript. VS planned the study, contribute to writing the manuscript. NV contributed to the writing of the paper. EM contributed to the writing of the paper. RC contributed to the writing of the paper. CF contributed to the writing of the paper. MG contributed to the writing of the paper. LV contributed to the writing of the paper. RF contributed to the writing of the paper. JM contributed to the writing of the paper. $\mathrm{CD}$ contributed to the writing of the paper. RE contributed to the writing of the paper.

Bilenko, N., Brunekreef, B., Beelen, R., Eeftens, M., DeHoogh, K., Hoek, G., et al. (2015). Associations between particulate matter composition and childhood blood pressure. The PIAMA study. Environ. Int. 84, 1-6. doi: 10.1016/j.envint.2015.07.010

Blass, J. P., and Gibson, G. E. (1991). The role of oxidative abnormalities in the pathophysiology of Alzheimer's disease. Rev. Neuro. 147, 513-525.

Block, M. L., and Calderón-Garcidueñas, L. (2009). Air pollution: mechanisms of neuroinflammation and CNS disease. Trends Neurosci. 32, 506-516. doi: 10.1016/j.tins.2009.05.009

Bolton, J. L., Smith, S. H., Huff, N. C., Gilmour, M. I., Foster, W. M., Auten, R. L., et al. (2012). Prenatal air pollution exposure induces neuroinflammation and predisposes offspring to weight gain in adulthood in a sex-specific manner. FASEB J. 26, 4743-4754. doi: 10.1096/fj.12-210989

Brickman, A. M., Khan, U. A., Provenzano, F. A., Yeiung, L. K., Suzuki, W., Schroeter, H., et al. (2014). Enhancing dentate gyrus function with dietary flavonols improves cognition in older adults. Nat. Neurosci. 17, 1798-1803. doi: 10.1038/nn.3850

Broadway, J. M., Redick, T. S., and Engle, R. W. (2010). "Working memory capacity: self-control is (in) the goal," in Self Control in Society, Mind, and Brain, eds R. Hassin, K. N. Ochsner, and Y. Trope (New York, NY: Oxford University Press), 163-173.

Calderón-Garcidueñas, L., Azzarelli, B., Acuña, H., Garcia, R., Gambling, T. M., Osnaya, N., et al. (2002). Air pollution and brain damage. Toxicol. Pathol. 30, 373-389. doi: 10.1080/01926230252929954

Calderón-Garcidueñas, L., Engle, R., Mora-Tiscareño, A., Styner, M., GómezGarza, G., Zhu, H., et al. (2011). Exposure to severe urban pollution influences cognitive outcomes, brain volume and systemic inflammation in clinically healthy children. Brain Cogn. 77, 345-355. doi: 10.1016/j.bandc.2011. 09.006 
Calderón-Garcidueñas, L., Franco-Lira, M., D’Angiulli, A., Rodriguez-Diaz, J., Blaurock-Busch, E., Busch, I., et al. (2015d). Mexico City normal weight children exposed to High concentrations of ambient PM2.5 show High blood leptin and endothelin-1, vitamin D deficiency, and food reward hormone dysregulation versus low pollution controls. Relevance for obesity and Alzheimer disease. Environ. Res. 140, 579-592. doi: 10.1016/j.envres.2015.05.012

Calderón-Garcidueñas, L., Franco-Lira, M., Mora-Tiscareño, A., Medina-Cortina, H., Torres-Jardón, R., and Kavanaugh, M. (2013a). Early Alzheimer's and Parkinson's disease pathology in urban children: friend versus Foe responsesIt is time to face the evidence. Biomed Res. Int. 2013:161687. doi: 10.1155/2013/ 161687

Calderón-Garcidueñas, L., Chao, C. K., Thompson, C., Rodríguez-Díaz, J., Franco-Lira, M., Mukherjee, P. S., et al. (2015a). CSF biomarkers: low amyloid$\beta_{1-42}$ and BDNF and high IFN $\gamma$ differentiate children exposed to Mexico City high air pollution v controls. Alzheimer's Disease Uncertainties. J. Alzheimer Dis. Parkinson. 5:189. doi: 10.4172/2161-0460.1000189

Calderón-Garcidueñas, L., Gónzalez-Maciel, A., Vojdani, A., Franco-Lira, M., Reynoso-Robles, R., Montesinos-Correa, H., et al. (2015g). The intestinal barrier in air pollution-associated neural involvement in Mexico City residents: mind the Gut, the evolution of a changing paradigm relevant to Parkinson disease risk. Alzheimers Dis. Parkinson. 5:179. doi: 10.4172/2161-0460.1000179

Calderón-Garcidueñas, L., Jewells, V., Galaz-Montoya, C., van Zundert, B., PérezCalatayud, A., Ascencio-Ferrel, E., et al. (2016). Interactive and additive influences of Gender, BMI and Apolipoprotein 4 on cognition in children chronically exposed to high concentrations of PM2.5 and ozone. APOE 4 females are at highest risk in Mexico City. Environ Res. 150, 411-422. doi: 10.1016/j.envres.2016.06.026

Calderón-Garcidueñas, L., Kavanaugh, M., Block, M., D’Angiulli, A., DelgadoChávez, R., Torres-Jardón, R., et al. (2012a). Neuroinflammation, hyperphosphorilated tau, diffuse amyloid plaques and down- regulation of the cellular prion protein in air pollution exposed children and adults. J. Alzheimer Dis. 28, 93-107. doi: 10.3233/JAD-2011-110722

Calderón-Garcidueñas, L., Macías-Parra, M., Hoffmann, H. J., Valencia-Salazar, G., Henríquez-Roldán, C., Monte, O. C., et al. (2009). Immunotoxicity and Environment: Immunodysregulation and Systemic Inflammation in Children. Toxicol. Pathol. 37, 161-169. doi: 10.1177/0192623308329340

Calderón-Garcidueñas, L., Maronpot, R. R., Torres-Jardón, R., Henríquez-Roldán, C., Schoonhoven, R., Acuña-Ayala, H., et al. (2003). DNA damage in nasal and brain tissues of canines exposed to air pollutants is associated with evidence of chronic brain inflammation and neurodegeneration. Toxicol. Pathol. 31, 524-538. doi: 10.1080/01926230390226645

Calderón-Garcidueñas, L., Mora-Tiscareño, A., Franco-Lira, M., Cross, J. V., Engle, R., Aragón-Flores, M., et al. (2013b). Flavonol-rich dark cocoa significantly decreases plasma endothelin-1 and improves cognition in urban children. Front. Pharmacol. 4:104. doi: 10.3389/fphar.2013.00104

Calderón-Garcidueñas, L., Mora-Tiscareño, A., Franco-Lira, M., Zhu, H., Lu, Z., Solorio, E., et al. (2015b). Decreases in short term memory, IQ, and Altered Brain metabolic ratios in urban Apolipoprotein 84 children exposed to air pollution. J. Alzheimers Dis. 45, 757-770. doi: 10.3233/JAD-142685

Calderón-Garcidueñas, L., Mora-Tiscareño, A., Melo-Sánchez, G., RodríguezDíaz, J., Torres-Jardón, R., Styner, M., et al. (2015e). A critical proton MR spectroscopy marker of Alzheimer's disease early neurodegenerative change: low hippocampal NAA/Cr ratio impacts APOE 4 Mexico City children and their parents. J. Alzheimers Dis. 48, 1065-1075. doi: 10.3233/JAD-150415

Calderón-Garcidueñas, L., Mora-Tiscareño, A., Ontiveros, E., Gómez-Garza, G., Barragán-Mejía, G., Broadway, J., et al. (2008b). Air pollution, cognitive deficits and brain abnormalities: A pilot study with children and dogs. Brain Cogn. 68, 117-127. doi: 10.1016/j.bandc.2008.04.008

Calderón-Garcidueñas, L., Mora-Tiscareño, A., Styner, M., Gómez-Garza, G., Zhu, H., Torres-Jardón, R., et al. (2012b). White matter hyperintensities, systemic inflammation, brain growth, and cognitive functions in children exposed to air pollution. J. Alzheimers Dis. 31, 183-191. doi: 10.3233/JAD-2012-120610

Calderón-Garcidueñas, L., Reynoso-Robles, R., Vargas- Martínez, J., GómezMaqueo-Chew, A., Pérez-Guillé, B., Mukherjee, P. S., et al. (2015f). Prefrontal White matter pathology in air pollution exposed Mexico City young urbanites and their potential impact on neurovascular unit dysfunction and the development of Alzheimer's disease. Environ. Res. 146, 404-417. doi: 10.1016/j. envres.2015.12.031
Calderón-Garcidueñas, L., Serrano-Sierra, A., Torres-Jardón, R., Zhu, H., Yuan, Y., Smith, D., et al. (2013c). The impact of environmental metals in young urbanites' brains. Exp. Toxicol. Pathol. 65, 503-511. doi: 10.1016/j.etp.2012.02.006

Calderón-Garcidueñas, L., Solt, A. C., Henríquez-Roldán, C., Torres-Jardón, R., Nuse, B., Herritt, L., et al. (2008a). Long-term air pollution exposure is associated with neuroinflammation, an altered innate immune response, disruption of the blood-brain-barrier, ultrafine particulate deposition, and accumulation of amyloid beta- 42 and alpha-synuclein in children and young adults. Toxicol. Pathol. 36, 289-310. doi: 10.1177/0192623307313011

Calderón-Garcidueñas, L., and Torres-Jardón, R. (2012). Air pollution, socioeconomic status, and children's cognition in megacities: the Mexico City Scenario. Front. Psychol. 3:217. doi: 10.3389/fpsyg.2012.00217

Calderón-Garcidueñas, L., Villarreal-Calderon, R., Valencia-Salazar, G., Henríquez-Roldán, C., Gutiérrez-Castrellón, P., Torres-Jardón, R., et al. (2008c). Systemic inflammation, endothelial dysfunction, and activation in clinically healthy children exposed to air pollutants. Inhal. Toxicol. 20, 499-506. doi: 10.1080/08958370701864797

Calderón-Garcidueñas, L., Vincent, R., Mora-Tiscareño, A., Franco-Lira, M., Henríquez-Roldán, C., Barragán-Mejía, G., et al. (2007). Elevated plasma endothelin-1 and pulmonary arterial pressure in children exposed to air pollution. Environ. Health Perspect. 115, 1248-1253. doi: 10.1289/ehp.9641

Calderón-Garcidueñas, L., Vojdani, A., Blaurock-Busch, E., Busch, I., Friedle, A., Franco-Lira, M., et al. (2015c). Air pollution and children: neural and tight junction antibodies and combustion metals, the role of barrier breakdown and brain immunity in neurodegeneration. J. Alzheimer's Dis. 43, 1039-1058. doi: 10.3233/JAD-141365

Campbell, A., Araujo, J. A., Li, H., Sioutas, C., and Kleinman, M. (2009). Particulate matter induced enhancement of inflammatory markers in the brains of apolipoprotein E knockout mice. J. Nanosci. Nanotechnol. 9, 5099-5104. doi: 10.1166/jnn.2009.GR07

Carson, J. L., Brighton, L. E., Collier, A. M., and Bromberg, P. A. (2013). Correlative ultrastructural investigations of airway epithelium following experimental exposure to defined air pollutants and lifestyle exposure to tobacco smoke. Inhal. Toxicol. 25, 134-140. doi: 10.3109/08958378.2013.763314

Cermakova, P., Johnell, K., Fastbom, J., Garcia-Ptacek, S., Lund, L. H., Winblad, B., et al. (2015). Cardiovascular disease in $\sim 30,000$ patients in the Swedish Dementia registry. J. Alzheimers Dis. 48, 949-958. doi: 10.3233/JAD-150499

Chapuis, P., Sauvée, M., Medici, M., Serra, A., Banciu, E., Moreau-Gaudry, A., et al. (2016). Morphologic and neuropsychological patterns in patients suffering from Alzheimer's disease. Neuroradiology 58, 459-666. doi: 10.1007/s00234016-1659-0

Cifuentes-Gómez, T., Rodriguez-Mateos, A., Gónzalez-Salvador, I., Alañon, M. E., and Spencer, J. P. (2015). Factors affecting the absorption, metabolism and excretion of cocoa flavonols in humans. J.Agri. Food Chem. 63, 7615-7623. doi: 10.1021/acs.jafc.5b00443

Costa, L. G., Cole, T. B., Coburn, J., Chang, Y. C., Dao, K., and Roque, P. (2014). Neurotoxicants are in the air: convergence of human, animal, and in vitro studies on the effects of air pollution on the brain. Biomed. Res. Int. 2014:736385. doi: 10.1155/2014/736385

Crawford, T. J., Devereaux, A., Higham, S., and Kelly, C. (2015). The disengagement of visual attention in Alzheimer's disease: a longitudinal eyetracking study. Front. Aging Neurosci. 7:118. doi: 10.3389/fnagi.2015.00118

Crawford, T. J., Higham, S., Renvoize, T., Patel, J., Dale, M., Suriya, A., et al. (2005). Inhibitory control of saccadic eye movements and cognitive impairment in Alzheimer's disease. Biol. Psychiatry 57, 1052-1060. doi: 10.1016/j.biopsych.2005.01.017

Crawford, T. J., and Highm, S. (2016). Distinguishing between impairments of working memory and inhibitory control in cases of early dementia. Neuropsychologia 81, 61-67. doi: 10.1016/j.neuropsychologia.2015.12.007

Crawford, T. J., Highm, S., Mayes, J., Dale, M., Shaunak, S., and Lekwuwa, G. (2013). The role of working memory and attentional disengagement on inhibitory control:effects of aging and Alzheimer's disease. Age (Dordr.) 35, 1637-1650. doi: 10.1007/s11357-012-9466-y

Daneman, M., and Carpenter, P. A. (1980). Individual differences in working memory and reading. J. Verbal Learn. Verbal Behav. 19, 450-466. doi: 10.1016/S0022-5371(80)90312-6

Declerck, K., Vel Szic, K. S., Palagani, A., Heyninck, K., Haegeman, G., Morand, C., et al. (2016). Epigenetic control of cardiovascular health 
by nutritional polyphenols involves multiple chromatin-modifying writer-reader-eraser proteins. Curr. Topics Med. Chem. 16, 788-806. doi: $10.2174 / 1568026615666150825141720$

Dehkordi, N., Rao, D. R., Warren, A. P., and Chawan, C. B. (1995). Lactose malabsorption as influenced by chocolate milk, skim milk, sucrose, whole milk and lactic cultures. J. Am. Dietet. Assoc. 95, 484-486. doi: 10.1016/S00028223(95)00126-3

De la Monte, S. M. (2014). Type 3 diabetes is sporadic Alzheimer's disease: mini-review. Eur. Neuropsychopharmacol. 24, 1954-1960. doi: 10.1016/j.euroneuro.2014.06.008

Desideri, G., Kwik-Uribe, C., Grassi, D., Necozione, S., Ghiadoni, L., Mastroiacovo, D., et al. (2012). Benefits in cognitive function, blood pressure, and insulin resistance through cocoa flavonol consumption in elderly subjects with mild cognitive impairment: the Cocoa, Cognition, and Aging (CoCoA) study. Hypertension 60, 794-801. doi: 10.1161/HYPERTENSIONAHA.112.193060

Driscoll, I., Resnick, S. M., Troncoso, J. C., An, Y., O’Brien, R., and Zonderman, A. B. (2006). Impact of Alzheimer's pathology on cognitive trajectories in non-demented elderly. Annu. Neurol. 60, 688-695. doi: 10.1002/ana.21031

Dubner, L., Wang, J., Ho, L., Ward, L., and Pasinetti, G. M. (2015). Recommendations for development of new standardized forms of cocoa breeds and cocoa extract processing for the prevention of Alzheimer's disease: role of cocoa in promotion of cognitive resilience and healthy brain aging. J. Alzheimers Dis. 48, 879-889. doi: 10.3233/JAD-150536

Ekstrom, R. B., French, J. W., Harman, H. H., and Dermen, D. (1976). Manual for Kit of Factor Referenced Cognitive Tests. Princeton, NJ: Educational Testing Service.

Engle, R. W. (2002). Working memory capacity as executive attention. Curr. Directions Psychol. Sci. 11, 19-23. doi: 10.1111/1467-8721.00160

Engle, R. W., and Kane, M. J. (2004). "Executive attention, working memory capacity, and a two-factor theory of cognitive control," in The Psychology of Learning and Motivation, Vol. 44, ed B. Ross (New York, NY: Elsevier), 145-199.

Englund, E., and Brun, A. (1990).White matter changes in dementia of Alzheimer's type: the difference in vulnerability between cell compartments. Histopathology 16, 433-439. doi: 10.1111/j.1365-2559.1990.tb01542.x

Eriksen, B. A., and Eriksen, C. W. (1974). Effects of noise letters upon the identification of a target letter in a nonsearch task. Percept. Psychophys. 16, 143-149. doi: 10.3758/BF03203267

Faria, A., Meireles, M., Fernandes, I., Santos-Buelga, C., Gonzalez-Manzano, S., Dueñas, M., et al. (2014). Flavonoid metabolites transport across a human BBB model. Food Chem. 149, 190-196. doi: 10.1016/j.foodchem.2013.10.095

Ferri, C., Desideri, G., Ferri, L., Proietti, I., Di Agostino, S., Martella, L., et al. (2015). Cocoa, blood pressure and cardiovascular health. J. Agric. Food Chem. 63, 9901-9909. doi: 10.1021/acs.jafc.5b01064

Field, D. T., Williams, C. M., and Butler, L. T. (2011). Consumption of cocoa flavanols results in an acute improvement in visual and cognitive functions. Physiol. Behav. 103, 255-260. doi: 10.1016/j.physbeh.2011.02.013

Fisher, N. D., Sorond, F. A., and Hollenberg, N. K. (2006). Cocoa flavonols and brain perfusion. J. Cardiovasc. Pharmacol. 47(Suppl. 2), S210-S214. doi: 10.1097/00005344-200606001-00017

Forns, J., Dadvand, P., Foraster, M., Alvarez-Pedrerol, M., Rivas, I., López-Vicente, M., et al. (2015). Traffic-related air pollution, noise at school and behavioral problems in Barcelona school children: a cross-sectional study. Environ. Health Perspect. 124, 529-535. doi: 10.1289/ehp.1409449

Francis, S. T., Head, K., Morris, P. G., and Macdonald, I. A. (2006). The effect of flavanol-rich cocoa on the fMRI response to a cognitive task in healthy young people. J. Cardiovasc. Pharmacol. 47, S215-S220. doi: 10.1097/00005344200606001-00018

Gehr, P., Clift, M. J., Brandenberger, C., Lehmann, A., Herzog, F., and RothenRutishauser, B. (2011). Endocytosis of environmental and engineered micro- and nanosized particles. Compr. Physiol. 1, 1159-1174. doi: 10.1002/cphy.c100035

Gerlofs-Nijland, M. E., van Berlo, D., Cassee, F. R., Schins, R. P., Wang, K., and Campbell, A. (2010). Effect of prolonged exposure to diesel engine exhaust on proinflammatory markers in different regions of the rat brain. Part. Fibre Toxicol. 7:12. doi: 10.1186/1743-8977-7-12

Gormaz, J., Valls, N., Sotomayor, C., Turner, T., and Rodrigo, R. (2016). Potential role of polyphenols in the prevention of cardiovascular diseases molecular bases. Curr. Med. Chem. 23, 115-128. doi: $10.2174 / 0929867323666151127201732$

Grassi, D., Ferri, C., and Desideri, G. (2015a). Brain protection and cognitive function: cocoa flavonoids as nutraceuticals. Curr. Pharm. Des. 22, 145-151. doi: $10.2174 / 1381612822666151112145730$

Grassi, D., Desideri, G., Mai, F., Martella, L., De Feo, M., Soddu, D., et al. (2015b). Cocoa, Glucose Tolerance, and Insulin Signaling: Cardiometabolic Protection. J. Agric. Food Chem. 63, 9919-9926. doi: 10.1021/acs.jafc.5b00913

Grober, E., Hall, C. B., Lipton, R. B., Zonderman, A. B., Resnick, S. M., and Kawas, C. (2008). Memory impairment, executive dysfunction, and intellectual decline in preclinical Alzheimer's disease. J. Int. Neuropsychol. Soc. 14, 266-278. doi: $10.1017 /$ s1355617708080302

Hajat, A., Hsia, C., and O’Neill, M. S. (2015). Socioeconomic disparities and air pollution exposure: a Global Review. Curr. Environ. Health Report. 2, 440-450. doi: 10.1007/s40572-015-0069-5

Hartz, A. M., Bauer, B., Block, M. L., Hong, J. S., and Miller, D. S. (2008). Diesel exhaust particles induce oxidative stress, proinflammatory signaling and $\mathrm{P}$ glycoprotein up-regulation at the blood-brain-barrier. FASEB J. 22, 2723-2733. doi: 10.1096/fj.08-106997

Hassenstab, J., Monsell, S. E., Mock, C., Roe, C. M., Cairns, N. J., Morris, J. C., et al. (2015). Neuropsychological markers of cognitive decline in persons with Alzheimer disease neuropathology. J. Neuropathol. Exper. Neurol. 74, 1086-1092. doi: 10.1097/NEN.0000000000000254

Hedden, T., Mormino, E. C., Amariglio, R. E., Younger, A. P., Schultz, A. P., Becker, J. A., et al. (2012). Cognitive profile of amyloid burden and white matter hyperintensities in cognitively normal older adults. J. Neurosci. 32, 16233-16242. doi: 10.1523/JNEUROSCI.2462-12.2012

Heiss, C., Dejam, A., Kleinbongard, P., Schewe, T., Sies, H., and Kelm, M. (2003). Vascular effects of cocoa rich in flavan-3-ols. JAMA 290, 1030-1031. doi: 10.1001/jama.290.8.1030

Howieson, D. B., Carlson, N. E., Moore, M. M., Wasserman, D., Abendroth, C. D., Payne-Murphy, J., et al. (2008). Trajectory of mild cognitive impairment onset. J. Int. Neuropsychol. Soc. 14, 192-198. doi: 10.1017/s1355617708080375

Hutchison, K. A. (2011). The interactive effects of list wide control, item-based control, and working memory capacity on Stroop performance. J. Exp. Psychol. Learn. Mem. Cogn. 37, 851-860. doi: 10.1037/a0023437

Joubert, S., Gour, N., Guedj, E., Didic, M., Guériot, C., Koric, L., et al. (2016). Earlyonset and late-onset Alzheimer's disease are associated with distinct patterns of memory impairment. Cortex 74, 217-232. doi: 10.1016/j.cortex.2015.10.014

Jumar, A., and Schmieder, R. E. (2016). Cocoa flavanol cardiovascular effects beyond Blood pressure reduction. J. Clin. Hyperten. 18, 352-358. doi: 10.1111/ jch. 12715

Jung, C. R., Lin, Y. T., and Hwang, B. F. (2015). Ozone, particulate matter, and newly diagnosed Alzheimer's disease: a population-based cohort study in Taiwan. J. Alzheimers Dis. 44, 573-584. doi: 10.3233/JAD-140855

Kane, M. J., Bleckley, M. K., Conway, A. R., and Engle, R. W. (2001). A controlledattention view of working-memory capacity. J. Exp. Psychol. Gen. 130, 169-183. doi: 10.1037/0096-3445.130.2.169

Kane, M. J., Conway, A. R. A., Hambrick, D. Z., and Engle, W. R. (2007). "Variation in working memory capacity as variation in executive attention and control," in Variation in Working Memory, eds A. R. A. Conway, C. Jarrold, M. J. Kane, A. Mijake, and J. N. Towse (New York, NY: Oxford University Press), 21-48.

Kane, M. J., Hambrick, D. Z., Tuholski, S. W., Wilhelm, O., Payne, T. W., and Engle, R. W. (2004). The generality of working memory capacity: a latent-variable approach to verbal and visuospatial memory span and reasoning. J. Exper. Psychol. Gen. 133, 189-217. doi: 10.1037/0096-3445. 133.2.189

Kane, M. J., and McVay, J. C. (2012). What mind wandering reveals about executive-control abilities and failures. Curr. Dir. Psychol. Sci. 21, 348-354. doi: $10.1177 / 0963721412454875$

Kantarci, K., Lowe, V., Przybelski, S. A., Weigand, S. D., Senjem, M. L., Ivnik, R. J., et al. (2012). APOE modifies the association between $A \beta$ load and cognition in cognitively normal older adults. Neurology 78, 232-240. doi: 10.1212/WNL.0b013e31824365ab

Karmakar, A., Zhang, Q., and Zhang, Y. (2014). Neurotoxicity of nanoscale materials. J. Food Drug Analog. 22, 147-160. doi: 10.1016/j.jfda.2014.01.012

Kish, L., Hotte, N., Kaplan, G. G., Vincent, R., Tso, R., Gänzle, M., et al. (2013). Environmental particulate matter induces murine intestinal inflammatory 
responses and alters the gut microbiome. PLoS ONE 8:e62220. doi: 10.1371/journal.pone.0062220

Latif, R. (2013). Health benefits of cocoa. Curr. Opin. Clin. Nutrit. Metabol. Care 16, 669-674. doi: 10.1097/MCO.0b013e328365a235

Levesque, S., Surace, M. J., McDonald, J., and Block, M. L. (2011a). Air pollution and the brain: Subchronic diesel exhaust exposure causes neuroinflammation and elevates early markers of neurodegenerative disease. J. Neuroinfl. 8:105. doi: 10.1186/1742-2094-8-105

Levesque, S., Taetzsch, T., Lull, M. E., Johnson, J. A., McGraw, C., and Block, M. L. (2013). The role of MAC1 in diesel exhaust particle-induced microglial activation and loss of dopaminergic neuron function. J. Neurochem. 125, 756-765. doi: 10.1111/jnc.12231

Levesque, S., Taetzsch, T., Lull, M. E., Kodavanti, U., Stadler, K., Wagner, A., et al. (2011b). Diesel exhaust activates and primes microglia: air pollution, neuroinflammation and regulation of dopaminergic neurotoxicity. Environ. Health Perspect. 119, 1149-1155. doi: 10.1289/ehp.1002986

Lippmann, M., Chen, L. C., Gordon, T., Ito, K., and Thurston, G. D. (2013). National particle component toxicity (NPACT) initiative: integrated epidemiologic and toxicologic studies of the health effects of particulate matter components. Res. Rep. Health Eff. Inst. 177, 5-13.

Ljubimova, J. Y., Kleinman, M. T., Karabalin, N. M., Inoue, S., Konda, B., Gangalum, P., et al. (2013). Gene expression changes in rat brain after short and long exposures to particulate matter in Los Angeles basin air: comparison with human brain tumors. Exper. Toxicol. Pathol. 65, 1063-1071. doi: 10.1016/j.etp.2013.04.002

Massee, L. A., Ried, K., Pase, M., Travica, N., Yoganathan, J., Scholey, A., et al. (2015). The acute and sub-chronic effects of cocoa flavonols on mood, cognitive and cardiovascular health in young healthy adults: a randomized, controlled trial. Front. Pharmacol. 6:93. doi: 10.3389/fphar.2015.00093

Milbury, P. E., and Kalt, W. (2010). Xenobiotic metabolism and berry flavonoid transport across the blood-brain barrier. J. Agric. Food Chem. 58, 3950-3956. doi: $10.1021 /$ jf903529m

Miller, M. D., Marty, M. A., and Landrigan, P. J. (2016). Children's environmental health: beyond national boundaries. Pediat. Clin. North Am. 63, 149-165. doi: 10.1016/j.pcl.2015.08.008

Molina, L. T., Madronich, S. J., Gaffney, J. S., Apel, E., de Foy, B., Fast, J., et al. (2010). An overview of the MILAGRO 2006 Campaign: Mexico City emissions and their transport and transformation. Atmosphere. Chem. Physiol. 10, 8697-8760. doi: 10.5194/acp-10-8697-2010

Monsell, S. E., Mock, C., Hassenstab, J., Roe, C. M., Cairns, N. J., Morris, J. C., et al. (2014). Neuropsychological changes in asymptomatic persons with Alzheimer disease neuropathology. Neurology 83, 434-440. doi: 10.1212/WNL.0000000000000650

Múgica, V., Torres, M., Salinas, E., Gutiérrez, M., and García, R. (2010). "Polycyclic aromatic hydrocarbons in the urban atmosphere of Mexico City," In Air Pollution, ed V. Villanyi (Croatia: InTech), 73-97.

Mushtaq, G., Khan, J. A., Joseph, E., and Kamal, M. A. (2015). Nanoparticles, neurotoxicity and neurodegenerative diseases. Curr. Drug Metab. 16, 676-684. doi: 10.2174/1389200216666150812122302

Naini, S. M. A., and Soussi-Yanicostas, N. (2015). Tau hyperphosphorilation and oxidative stress, a critical vicious circle in neurodegenerative tautopathies? Oxid. Med. Cell. Longev. 2015:151979. doi: 10.1155/2015/151979

Oppenheim, H. A., Lucero, J., Guyot, A. C., Herbert, L. M., McDonald, J. D., Mabondzo, A., et al. (2013). Exposure to vehicle emissions results in altered blood brain barrier permeability and expression of matrix metalloproteinases and tight junction proteins in mice. Part. Fibre Toxicol. 10:62. doi: 10.1186/1743-8977-10-62

Ostertag, L. M., O’Kennedy, N., Kroon, P. A., Duthie, G. G., and de Roos, B. (2010). Impact of dietary polyphenols on human platelet function-a critical review of controlled dietary intervention studies. Mol. Nutr. Food Res. 54, 60-81. doi: $10.1002 / \mathrm{mnfr} .200900172$

Owen, A. M. (2000). The role of the lateral frontal cortex in mnemonic processing: the contribution of functional neuroimaging. Exper. Brain Res. 133, 33-43. doi: 10.1007/s002210000398

Parra, M. A., Saarimäki, H., Bastin, M. E., Londoño, A. C., Pettit, L., Lopera, F., et al. (2015). Memory binding and white matter integrity in familial Alzheimer's disease. Brain 138, 1355-1369. doi: 10.1093/brain/awv048

Parveen, A., Rizvi, S. H., Sushma., Madhi, F., Ahmad, I., Singh, P. P., et al. (2015). Intranasal exposure to silica nanoparticles induce alterations in pro-inflammatory environment of rat brain: involvement of oxidative stress Toxicol. Ind. Health. doi: 10.1177/0748233715602985. [Epub ahead of print].

Pettigrew, C., Soldan, A., Moghekar, A., Wang, M. C., Gross, A. L., O’Brien, R., et al. (2015). Relationship between cerebrospinal fluid biomarkers of Alzheimer's disease and cognition in cognitively normal older adults. Neuropsychologia 78, 63-72. doi: 10.1016/j.neuropsychologia.2015.09.024

Pike, K. E., Savage, G., Villemagne, V. L., Ng, S., Moss, S. A., Maruff, P., et al. (2007). Beta-amyloid imaging and memory in non-demented individuals: evidence for preclinical Alzheimer's disease. Brain 130, 2837-2844. doi: 10.1093/brain/awm238

Prabhakaran, V., Narayanan, K., Zhao, Z., and Gabrieli, J. D. (2000). Integration of diverse information in working memory within the frontal lobe. Nat. Neurosci. 3, 85-90. doi: 10.1038/71156

Price, J. L., McKeel, D. W. Jr., Buckles, V. D., Roe, C. M., Xiong, C., Grundman, M., et al. (2009). Neuropathology of non-demented aging: presumptive evidence for preclinical Alzheimer disease. Neurobiol. Aging 30, 1026-1036. doi: 10.1016/j.neurobiolaging.2009.04.002

Qin, L., Wu, X., Block, M. L., Liu, Y., Breese, G. R., Hong, J. S., et al. (2007). Systemic LPS causes chronic neuroinflammation and progressive neurodegeneration. Glia 55, 453-462. doi: 10.1002/glia.20467

Querol, X., Pey, J., Minguillón, M. C., Pérez, N., Alastuey, A., Viana, M., et al. (2008). PM speciation and sources in Mexico during the MILAGRO-2006 Campaign. atmosphere. Chem. Physiol. 8, 111-128. doi: 10.5194/acp-8-1112008

Ramos-Rodríguez, J. J., Jimenez-Palomares, M., Murillo-Carretero, M. I., InfanteGarcia, C., Berrocosos, E., Hernandez-Pacho, F., et al. (2015). Central vascular disease and exacerbated pathology in a mixed model of type 2 diabetes and Alzheimer's disease. Psychoneuroendocrinology 62, 69-79. doi: 10.1016/j.psyneuen.2015.07.606

Raven, J. (1990). Advanced Progressive Matrices. Oxford: Oxford Psychological Press.

Riley, K. P., Jicha, G. A., Davis, D., Abner, E. L., Cooper, G. E., Stiles, N., et al. (2011). Prediction of preclinical Alzheimer's disease: longitudinal rates of change in cognition. J. Alzheimers Dis. 25, 707-717. doi: 10.3233/JAD-2011102133

Rodriguez-Mateos, A., Oruna-Concha, M. J., Kwik-Uribe, C., Vidal, A., and Spencer, J. P. (2012). Influence of sugar type on the bioavailability of cocoa flavonols. Br. J. Nat. 108, 2243-2250. doi: 10.1017/S0007114512000475

Rossner, P. Jr., Tulupova, E., Rossnerova, A., Libalova, H., Honkova, K., Gmuender, H., et al. (2015). Reduced gene expression levels after chronic exposure to high concentrations of air pollutants. Mutat. Res. 780, 60-70. doi: 10.1016/j.mrfmmm.2015.08.001

Roura, E., Andrés-Lacueva, C., Estruch, R., Lourdes Mata Bilbao, M., IzquierdoPulido, M., and Lamuela-Raventós, R. M. (2008). The effects of milk as a food matrix for polyphenols on the excretion profile of cocoa (-) epicatechin metabolites in healthy human subjects. Br. J. Nat. 100, 846-851. doi: $10.1017 /$ s0007114508922534

Villarreal-Calderon, R., Torres-Jardon, R., Pérez-Guillé, B., Maronpot, R. R., Reed, W., Zhu, H., et al. (2010). Urban air pollution targets the dorsal vagal complex and dark chocolate offers neuroprotection. Int. J. Toxicol. 29, 604-615. doi: $10.1177 / 1091581810383587$

Sala, J. B., and Courtney, S. M. (2007). Binding of what and where during working memory maintenance. Cortex 43, 5-21. doi: 10.1016/S0010-9452(08)70442-8

Sansone, R., Rodriguez-Mateos, A., Heuel, J., Falk, D., Schuler, D., Wagstaff, R., et al. (2015). Cocoa flavonol intake improves endothelial function and Framingham risk score in healthy men and women: a randomized, controlled, double-masked trial: the Flaviola Health Study. Br. J. Nat. 114, 1246-1255. doi: $10.1017 /$ S0007114515002822

Sato, N., and Morishita, R. (2015). The roles of lipid and glucose metabolism in modulation of $\beta$-amyloid, tau and neurodegeneration in the pathogenesis of Alzheimer disease. Front. Aging Neurosci. 7:199. doi: 10.3389/fnagi.2015.00199

Schini-Kerth, V. (2014). Role of polyphenols in improving endothelial dysfunction in diabetes. Free Radic. Biol. Med. 75, S11-S12. doi: 10.1016/j.freeradbiomed.2014.10.858

Schmidt, R., Petrovic, K., Ropele, S., Enzinger, C., and Fazekas, F. (2007). Progression of leukoaraiosis and cognition. Stroke 38, 2619-2625. doi: 10.1161/STROKEAHA.107.489112

Scholey, A., and Owen, L. (2013). Effects of chocolate on cognitive function and mood: a systematic review. Nutr. Rev. 71, 665-681. doi: 10.1111/nure.12065 
Schramm, D. D., Karim, M., Schrader, H. R., Holt, R. R., Kirkpatrick, N. J., Polagruto, J. A., et al. (2003). Food effects on the absorption and pharmacokinetics of cocoa flavonols. Life Sci. 73, 857-869. doi: 10.1016/S00243205(03)00373-4

Schroeter, H., Holt, R. R., Orozco, T. J., Schmitz, H. H., and Keen, C. L. (2003). Nutrition: milk and absorption of dietary flavonols. Nature 426, 787-788. doi: $10.1038 / 426787 b$

Sharma, A., Muresanu, D. F., Patnaik, R., and Sharma, H. S. (2013). Size and age-dependent neurotoxicity of engineered metal nanoparticles in rats. Mol. Neurobiol. 48, 368-379. doi: 10.1007/s12035-013-8502-y

Sharma, H. S., and Sharma, A. (2012). Neurotoxicity of engineered nanoparticles from metals. CNS Neurol. Disord. Drug Targ. 11, 65-80. doi: 10.2174/187152712799960817

Shipstead, Z., Harrison, T. L., and Engle, R. W. (2015). Working memory capacity and the scope and control of attention. Attent. Percept. Psychophysiol. 77, 1863-1680. doi: 10.3758/s13414-015-0899-0

Shipstead, Z., and Lindsey, D. R. B., Marshall, R. L., Engle, R. W. (2014). The mechanisms of working memory capacity: primary memory, secondary memory and attention control. J. Mem. Lang. 72, 116-141. doi: 10.1016/j.jml.2014.01.004

Sjobeck, M., Haglund, M., and Englund, E. (2005). Decreasing myelin density reflected increasing white matter pathology in Alzheimer's diseasea neuropathological study. Int. J. Geriatr. Psychiatry 20, 919-926. doi: 10.1002/gps.1384

Smith, M. A., Zhu, X., Tabaton, M., Liu, G., McKeel, D. W. Jr., Cohen, M. L., et al. (2010). Increased iron and free radical generation in preclinical Alzheimer disease and mild cognitive impairment. J. Alzheimers Dis. 19, 363-372. doi: 10.3233/JAD-2010-1239

Sokolov, A. N., Pavlova, M. A., Klosterhalfen, S., and Enck, P. (2013). Chocolate and the brain: neurobiological impact of cocoa flavonols on cognition and behavior. Neurosci. Biobehav. Rev. 37, 2445-2453. doi: 10.1016/j.neubiorev.2013.06.013

Son, S. J., Lee, K. S., Lee, Y., Baek, J. H., Choi, S. H., Na, D. L., et al. (2012). Association between white matter hyperintensity severity and cognitive impairment according to the presence of the apolipoprotein E (APOE) $\varepsilon 4$ allele in the elderly: retrospective analysis of data from the CREDOS study. J. Clin. Psychiatry 73, 1555-1562. doi: 10.4088/JCP.12m07702

Sorond, F. A., Hollenberg, N. K., Panych, L. P., and Fisher, N. D. (2010). Brain blood flow and velocity: correlations between magnetic resonance and transcranial Doppler sonography. J. Ultrasound Med. 29, 1017-1022.

Sperling, R. A., Aisen, P. S., Beckett, L. A., Bennett, D. A., Craft, S., Fagan, A. M., et al. (2011). Toward defining the preclinical stages of Alzheimer's disease: recommendations from the National Institute on Aging-Alzheimer's Association workgroups on diagnostic guidelines for Alzheimer's disease. Alzheimers Dement. 7, 280-292. doi: 10.1016/j.jalz.2011.03.003

Stringer, T. P., Guerrieri, D., Vivar, C., and Van Praag, H. (2015). Plantderived flavonol (-)epicatechin mitigates anxiety in association with elevated hippocampal monoamine and BDNF levels, but does not influence pattern separation in mice. Transl. Psychiatry 5, 493. doi: 10.1038/tp.2014.135

Thomson, E. M., Kumarathasan, P., Calderón-Garcidueñas, L., and Vincent, R. (2007). Air Pollution alters brain and pituitary endothelin-1 and inducible nitric oxide synthase gene expression. Environ. Res. 105, 224-233. doi: 10.1016/j.envres.2007.06.005

Thurstone, L. L. (1938). Primary Mental Abilities. Chicago, IL: University of Chicago Press.

Tian, L., Lin, B., Wu, L., Li, K., Liu, H., Yan, J., et al. (2015). Neurotoxicity induced by zinc oxide nanoparticles: age-related differences and interaction. Sci. Rep. 5:16117. doi: 10.1038/srep16117

Tsamou, M., Vrijens, K., Madhloum, N., Lefebvre, W., Vanpoucke, C., and Nawrot, T. S. (2016). Air pollution-induced placental epigenetic alterations in early life: a candidate miRNA approach. Epigenetics. doi: 10.1080/15592294.2016. 1155012. [Epub ahead of print].

Twamley, E. W., Ropacki, S. A., and Bondi, M. W. (2006). Neuropsychological and neuroimaging changes in preclinical Alzheimer's disease. J. Int. Neuropsychol. Soc. 12, 707-735. doi: 10.1017/s1355617706060863

Ucciferri, N., Collnot, E. M., Gaiser, B. K., Tirella, A., Stone, V., Domenici, C., et al. (2014). In vitro toxicological screening of nanoparticles on primary human endothelial cells and the role of flow in modulating cell response. Nanotoxicology 8, 697-708. doi: 10.3109/17435390.2013.831500

Unsworth, N., Redick, T. S., Heitz, R. P., Broadway, J. M., and Engle, R. W. (2009). Complex working memory span tasks and higher order cognition: a latentvariable analysis of the relationship between processing and storage. Memory 17, 635-654. doi: 10.1080/09658210902998047

Unsworth, N., and Spillers, G. J. (2010). Variation in working memory capacity and episodic recall: the contributions of strategic encoding and contextual retrieval. Psych. Bull. Rev. 17, 200-205. doi: 10.3758/PBR.17.2.200

Van Praag, H., Lucero, M. J., Yeo, G. W., Stecker, K., Heivand, N., Zhao, C., et al. (2007). Plant-derived flavanol (-)epicatechin enhances angiogenesis and retention of spatial memory in mice. J. Neurosci. 27, 5869-5878. doi: 10.1523/JNEUROSCI.0914-07.2007

Vega, E., Eidels, S., Ruiz, H., López-Veneroni, D., Sosa, G., Gónzalez, E., et al. (2010). Particulate air pollution in Mexico City: a detailed view. Aerosol. Air Qual. Res. 10, 193-211. doi: 10.4209/aaqr.2009.06.0042

Villemagne, V. L., Pike, K. E., Chételat, G., Ellis, K. A., Mulligan, R. S., Bourgeat, P., et al. (2011). Longitudinal assessment of $A \beta$ and cognition in aging and Alzheimer disease. Annu. Neurol. 69, 181-192. doi: 10.1002/ana.22248

Wang, J., Santa-Maria, I., Ho, L., Ksiezak-Reding, H., Ono, K., Teplow, D. B., et al. (2010). Grape derived polyphenols attenuate tau neuropathology in a mouse model of Alzheimer's disease. J. Alzheimers Dis. 22, 653-661. doi: 10.3233/JAD2010-101074

Wang, J., Varghese, M., Ono, K., Yamada, M., Levine, S., Tzavaras, N., et al. (2014). Cocoa extracts reduce oligomerization of amyloid- $\beta$ : implications for cognitive improvement in Alzheimer's disease. J. Alzheimers Dis. 41, 643-650. doi: 10.3233/JAD-132231

Wang, X., Wang, W., Li, L., Perry, G., Lee, H. G., and Zhu, X. (2014). Oxidative stress and mitochondrial dysfunction in Alzheimer's disease. Biochem. Biophy. Acta 1842, 1240-1247. doi: 10.1016/j.bbadis.2013.10.015

Win-Shwe, T. T., Fujitani, Y., Kyi-Tha-Thu, C., Furuyama, A., Michikawa, T., Tsukahara, S., et al. (2014). Effects of diesel engine exhaust origen secondary organic aerosols on novel object recognition ability and maternal behavior in BALB/c mice. Int. J. Environ. Res. Public Health 11, 11286-11307. doi: 10.3390/ijerph111111286

Yao, G., Yue, H., Yun, Y., and Sang, N. (2015). Chronic SO2 inhalation above environmental standard impairs neuronal behavior and represses glutamate receptor gene expression and memory-related kinase activation via neuroinflammation in rats. Environ. Res. 137, 85-93. doi: 10.1016/j.envres.2014.11.012

Yorifuji, T., Kashima, S., Higa Diez, M., Kado, Y., Sanada, S., and Doi, H. (2016). Prenatal exposure to traffic-related air pollution and child behavioral development milestone delays in Japan. Epidemiology 27, 57-65. doi: 10.1097/EDE.0000000000000361

Youdim, K. A., Shukitt-Hale, B., and Joseph, J. A. (2004). Flavonoids and the brain: interactions at the blood-brain barrier and their physiological effects on the central nervous system. Free Radic. Biol. Med. 37, 1683-1693. doi: 10.1016/j.freeradbiomed.2004.08.002

Conflict of Interest Statement: The authors declare that the research was conducted in the absence of any commercial or financial relationships that could be construed as a potential conflict of interest.

\section{Received: 18 March 2016; Accepted: 18 July 2016; Published: 11 August 2016}

Citation: Calderón-Garcidueñas L, San Juan Chávez V, Vacaseydel-Aceves NB, Calderón-Sánchez R, Macías-Escobedo E, Frías C, Giacometto M, Velasquez L, Félix-Villarreal R, Martin JD, Draheim C and Engle RW (2016) Chocolate, Air Pollution and Children's Neuroprotection: What Cognition Tools should be at Hand to Evaluate Interventions? Front. Pharmacol. 7:232. doi: 10.3389/fphar.2016.00232 Copyright (c) 2016 Calderón-Garcidueñas, San Juan Chávez, Vacaseydel-Aceves, Calderón-Sánchez, Macías-Escobedo, Frías, Giacometto, Velasquez, Félix-Villarreal, Martin, Draheim and Engle. This is an open-access article distributed under the terms of the Creative Commons Attribution License (CC BY). The use, distribution or reproduction in other forums is permitted, provided the original author(s) or licensor are credited and that the original publication in this journal is cited, in accordance with accepted academic practice. No use, distribution or reproduction is permitted which does not comply with these terms. 